\title{
DEVELOPMENT OF CAPACITIVE SENSOR FOR MEASURING SOIL WATER CONTENT $^{1}$
}

\section{ALAN K. RÊGO SEGUNDO ${ }^{2}$, JOSÉ H. MARTINS ${ }^{3}$, PAULO M. DE B. MONTEIRO 4 , RUBENS A. DE OLIVEIRA ${ }^{5}$, DELLY OLIVEIRA FILHO ${ }^{6}$}

\begin{abstract}
The irrigation management based on the monitoring of the soil water content allows for the minimization of the amount of water applied, making its use more efficient. Taking into account these aspects, in this work, a sensor for measuring the soil water content was developed to allow real time automation of irrigation systems. This way, problems affecting crop yielding such as irregularities in the time to turn on or turn off the pump, and excess or deficit of water can be solved. To develop the sensors were used stainless steel rods, resin, and insulating varnish. The sensors measuring circuit was based on a microcontroller, which gives its output signal in the digital format. The sensors were calibrated using soil of the type "Quartzarenic Neosoil". A third order polynomial model was fitted to the experimental data between the values of water content corresponding to the field capacity and the wilting point to correlate the soil water content obtained by the oven standard method with those measured by the electronic circuit, with a coefficient of determination of $93.17 \%$, and an accuracy in the measures of $\pm 0.010 \mathrm{~kg} \mathrm{~kg}^{-1}$. Based on the results, it was concluded that the sensor and its implemented measuring circuit can be used in the automation process of irrigation systems.
\end{abstract}

KEYWORDS: process control, control system, irrigation system.

\section{DESENVOLVIMENTO DE SENSOR CAPACITIVO PARA A MEDIÇÃO DO TEOR DE ÁGUA DO SOLO}

RESUMO: O manejo da irrigação, com base no monitoramento do teor de água do solo, permite racionalizar a quantidade de água aplicada, tornando o seu uso mais eficiente. Levando-se em conta esses aspectos, foi desenvolvido um sensor capacitivo de teor de água do solo e seu circuito de medição para que sistemas de irrigação possam ser automatizados. Desta forma, problemas que afetam a produtividade, tais como irregularidades no acionamento e aplicação de água de maneira excessiva ou deficiente, podem ser contornados. No desenvolvimento dos sensores, foram utilizadas hastes de aço inoxidável, resina e verniz isolante. O circuito de medição foi baseado em um microcontrolador, que disponibiliza um sinal de saída no formato digital. Os sensores foram calibrados, utilizando-se de solo do tipo neossolo quartzarênico. Um polinômio de terceira ordem foi ajustado aos dados experimentais, para correlacionar o teor de água do solo, obtido pelo método-padrão de estufa, com os sinais digitais correspondentes, medidos pelo circuito. Obtiveram-se um coeficiente de determinação de $93,17 \%$ e uma precisão nas medidas de $\pm 0,010 \mathrm{~kg} \mathrm{~kg}^{-1}$. Com base nos resultados obtidos, concluiu-se que o sensor desenvolvido e o circuito de medição implementado podem ser utilizados no processo de automação de sistemas de irrigação.

PALAVRAS-CHAVE: controle de processo, sistema de controle, sistema de irrigação.

\footnotetext{
${ }^{1}$ Part of the master degree dissertation presented by the first author to UFV.

${ }^{2}$ Doctorate student, Departamento de Engenharia Agrícola, UFV, Viçosa - MG, Brasil, Fone: 31-8866.6595, alan.segundo@ufv.br.

${ }^{3}$ Professor, Departamento de Engenharia Agrícola, UFV, Viçosa - MG, Brasil.

${ }^{4}$ Associate Professor, Departamento de Controle e Automação e de Técnicas Fundamentais, UFOP, Ouro Preto - MG, Brasil.

${ }^{5}$ Associate Professor, Departamento de Engenharia Agrícola, UFV, Viçosa - MG, Brasil.

${ }^{6}$ Associate Professor, Departamento de Engenharia Agrícola, UFV, Viçosa - MG, Brasil.

Recebido pelo Conselho Editorial em: 14-6-2010

Aprovado pelo Conselho Editorial em: 26-11-2010
} 


\section{INTRODUCTION}

The determination of the necessary water quantity for irrigation is one of the main parameters for the correct planning, dimensioning and management of any irrigation system, as well as for the evaluation of availability of hydric resources. When the quantity of necessary water is overestimated, as a consequence there are over dimensioned irrigation systems, increasing the cost of irrigation per unit of area (MANTOVANI et al., 2007).

The water application in excess can cause, many times, the elevation of the water table, soil salinization and leaching of the nutrients. On the other hand, when the quantity of the necessary water is underestimated, there is the sub-dimensioning of the irrigation system and, as a consequence, low yield or more frequently the incapacity of the system to irrigate the whole area of the project, that is, reduction of the area to be irrigated (BERNARDO et al., 2006).

In the literature, there are recommendations of fixed irrigation frequencies for each culture. Although it can be practical in a sense of programming the operations, this method has deficits and, or water excess, once that the climatic conditions vary during the year. Thus, there is the need to use field methods that determine, directly or indirectly, the hydric availability of the soil for the cultures, according to the prevailing environmental conditions during the development of the plants (QUEIROZ et al., 2005).

Irrigation control based on soil water status is one of the most useful methods of scheduling due to its practicability and low cost (SILVA et al., 2005).

The management of irrigation based on the monitoring of the soil water content enables rationalizing the quantity of water applied, making its use more efficient.

The concept of efficient water use includes any measures that reduces the quantity used per unit of production and that favors its maintenance (PAZ et al., 2000). This way, sustainable agriculture may be developed, assuring that there are enough resources for future generations.

To achieve the proper management of irrigation it is important to know the soil water content to, thereby, apply the amount of water needed during the correct time. In this context, the use of sensors is one of the more accurate ways to monitor the water content in the soil, and its implementation has brought several contributions to the agricultural environment (CRUZ et al., 2010).

The time domain reflectometry (TDR) technique for measuring the soil water content consists in determining the value of its dielectric constant. The water soil content is a function of the dielectric constant. This value is based on the time between the emission and the reflection of an electromagnetic pulse, emitted by a pulse generator, in parallel metal rods that work as "wave guides". In this case, the determined dielectric constant will be that of the material between the metal rods, that is, the soil's (OLIVEIRA FILHO et al., 2006).

Considering that the travel time of the electromagnetic pulse is very small, in the order of $10^{-9}$ second ( $1 \mathrm{~ns}$ ), the quantification technique must be sophisticated and demands a complex electronic equipment and, consequently, expensive (LACERDA et al., 2005).

The use of capacitance based sensors is one of the methods used to quantitatively measure soil water contents (SILVA et al., 2007).

In this project, capacitive sensors and its measuring circuit were developed to estimate the soil water content. The variation of the soil capacitance occurs due to the variation of its dielectric constant, which is correlated with the variation of its water content. Thus, it concerns the variation of the same measuring parameter used in the TDR method: the dielectric constant of the soil. However, the used devices (hardware) to measure the signal in the capacitive sensors are more simple and cheaper. 


\section{MATERIAL AND METHODS}

This work was developed in the Rural Electrification Laboratory and in the Hydraulics Laboratory, both of them belonging to the Department of Agricultural Engineering of the Federal University of Viçosa, in Viçosa, Minas Gerais, Brazil.

The work was carried out in three stages:

i - Development of the sensor to measure the soil water content;

ii - Development of the sensor's measuring circuit, and sensor calibration.

\section{SENSOR DEVELOPMENT}

The soil water content sensor was developed based on the indirect measurement of the dielectric constant of the soil material located between the three parallel stainless steel rods, coated with insulating material.

In the construction of the capacitive sensor the following were used: stainless steel rods, liquid polyester resin, coaxial cable with $50 \Omega$ impedance and insulating varnish like the one used in the windings for electric motors.

The construction and dimensioning procedure of the sensor were practically the same used with the TDR by SANTOS (2008), adding the insulating varnish. First, the stainless steel rods with $6 \mathrm{~mm}$ in diameter were cut in 21 pieces $13 \mathrm{~cm}$ long. Since each sensor has three rods, seven sensors were built. Next, each group of three rods was welded to $2 \mathrm{~m}$ of coaxial cable, and the rigid central wire of the cable was welded to one rod and its wire mesh was welded to the other two rods.

Then, these rods were placed vertically in a wooden built structure, in a way that they were parallel to each other spaced in $2 \mathrm{~cm}$ between them in each sensor. Next, a metal sheet mold was inserted in the superior part of this wooden structure, so that the resin could be leaked.

The resin was mixed to the catalyst during, approximately, ten minutes and then inserted in the metallic sheet mold. This way, the resin covered $3 \mathrm{~cm}$ of the length of the rods, leaving $10 \mathrm{~cm}$ of effective length to perform the sensor measurements.

To prevent that the sensors got stuck in the molds, they were removed before the resin hardened completely. Next, the rod in each sensor was coated with insulating varnish. The schematic on Figure 1 summarizes this procedure. However, only three sensors were depicted.

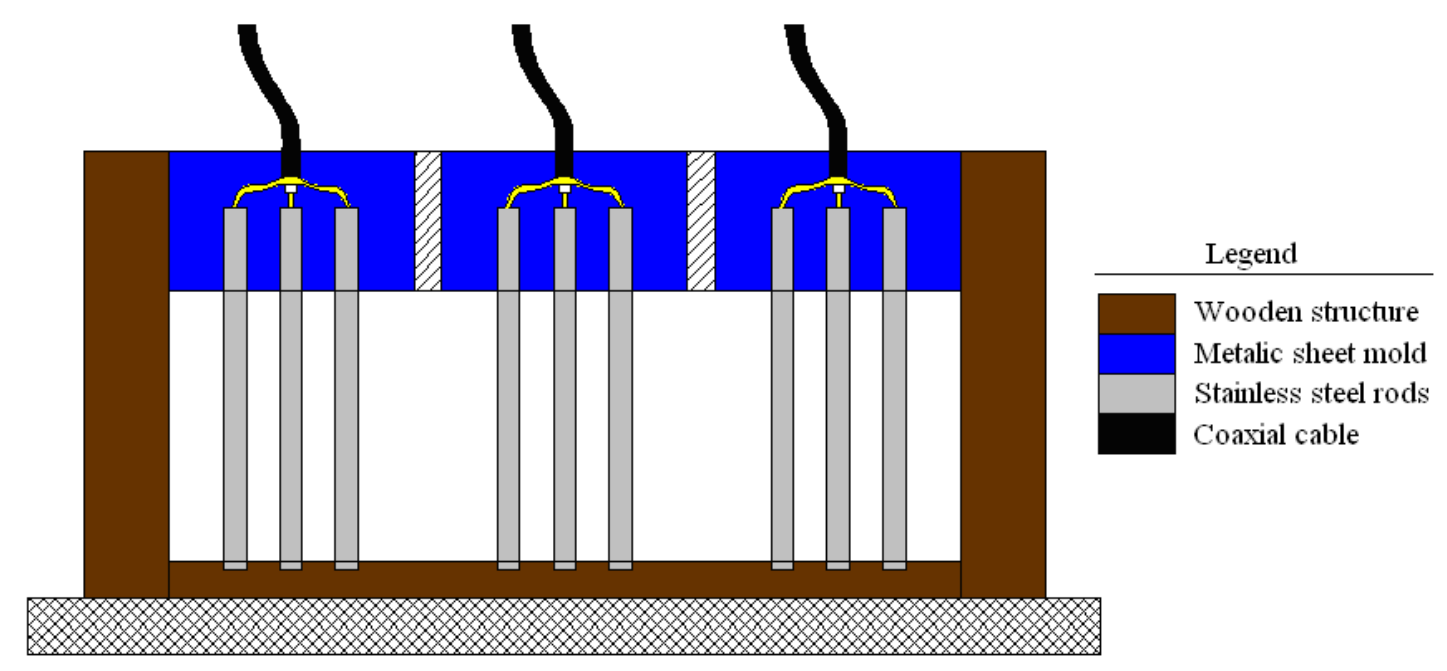

FIGURE 1. Construction schematics of the soil water content capacitive sensors. 


\section{MEASUREMENT CIRCUIT}

The measurement circuit developed to measure the capacitance variation of the soil material placed between the rods of the sensors was based in an alternating current bridge (Figure 2).

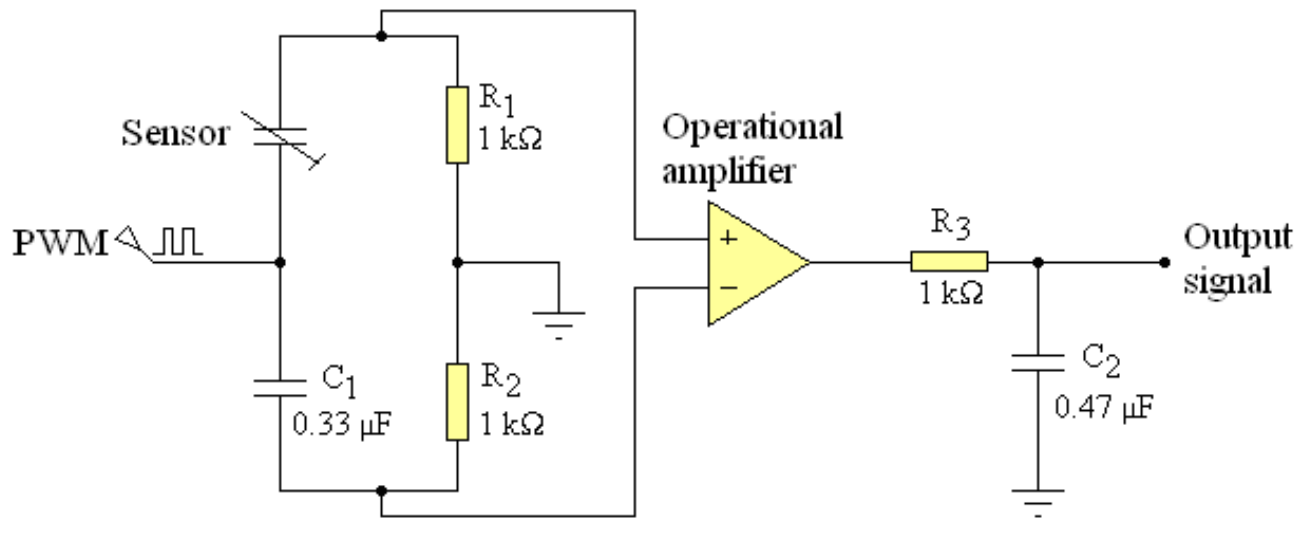

FIGURE 2. Capacitance measurement circuit using Alternating Current Bridge.

The balance of the bridge was adjusted to the lowest capacitance value of the sensor, that is, with it empty (with air between the rods).

This measurement circuit contains a microcontroller that, besides of providing a $625 \mathrm{kHz}$ square wave to feed the bridge, it converts the output analog signal of the circuit in a digital number of 10 binary digits (10 bits).

This microcontroller was programmed to execute 16 measurements of this signal at intervals of $10 \mathrm{~ms}$, and return its average. The output signal is available in the digital format, through the serial port.

\section{SENSOR CALIBRATION}

The sensors were calibrated taking into consideration the standard oven method. For such, three containers were constructed using a PVC pipe with a nominal diameter of $100 \mathrm{~mm}$, PVC cap with a diameter of $100 \mathrm{~mm}$, and nylon screen. The pipe was cut into $26 \mathrm{~cm}$ pieces and a hole of, approximately, $2 \mathrm{~cm}$ in diameter was made in the center of the cap so that the water can drain out. However, a nylon screen was placed over the hole to avoid that the soil also leaved the container.

The soil material used in this work was from a "quartzarenic neosoil" with known physicalhydric and chemical properties. A $14 \mathrm{~cm}$ height was established for the column of soil material in each container. Thus, since the internal diameter of the container is $98 \mathrm{~mm}$, for this height the volume is $1,056 \mathrm{dm}^{3}$. From the density of the soil of $1.49 \mathrm{~kg} \mathrm{dm}^{-3}$, the amount of soil for each container was calculated, obtaining the value of $1,573 \mathrm{~kg}$.

The three containers containing soil material were inserted in another container containing water during 72 hours to saturate the samples. Subsequently, the samples were removed and the sensors inserted into them, one in each sample. Then, the signals from these sensors were measured and the mass of each sample was determined, and the samples were placed in an oven for drying. This procedure was repeated daily (Figure 3). 


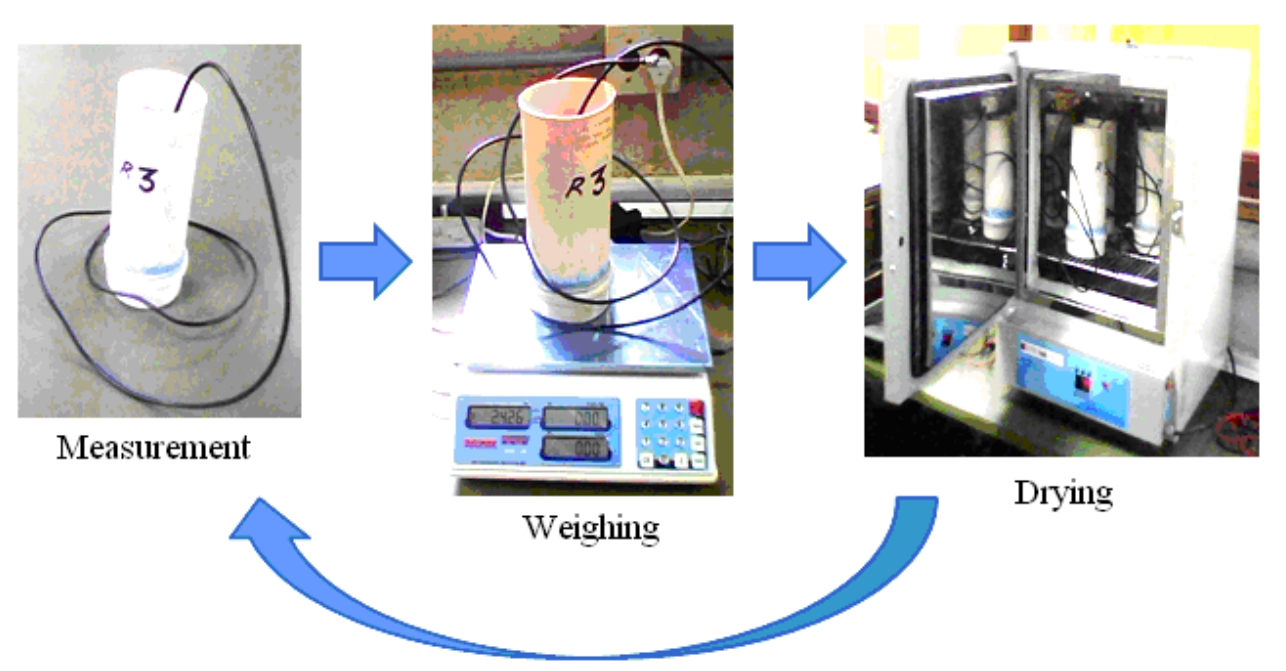

FIGURE 3. Procedures adopted in the calibration of the sensors.

During the experiment, the oven temperature was adjusted to approximately $65^{\circ} \mathrm{C}$.

After removing the samples from the oven enough time was waited until the temperature of the soil samples was reduced to approximately $35^{\circ} \mathrm{C}$.

When the change in the amount of water in the soil samples became practically constant, the soil samples were placed in glass containers and placed in an oven at $105^{\circ} \mathrm{C}$ during 24 hours to determine the mass of dried soil.

The mass of each container and of each sensor was determined separately before filling them with soil. Thus, at the end of the experiment, the water content of soil was calculated at each instant of measurement.

The soil water content is the ratio between the mass of water and the mass of dried soil, expressed in percentage by weight (BERNARDO et al., 2006).

From the experimental data of water content, a mathematical mode to estimate the water content of the soil, as a function of the measurements signals provided by the equipment, expressed by Equation 1, was fitted by linear regression.

$$
\mathrm{u}_{\mathrm{e}}=\sum_{\mathrm{i}=0}^{\mathrm{i}=3} \mathrm{a}_{\mathrm{i}} \mathrm{v}^{\mathrm{i}}
$$

where,

$\mathrm{u}_{\mathrm{e}}$ - estimated value of the soil water content, $\mathrm{kg} \mathrm{kg}^{-1}$;

$\mathrm{v}$ - voltage signal measured by the sensor, $\mathrm{V}$, and

$a_{i}$ - regression coefficients.

Since the purpose of the use of the sensor is to measure the water content aimed at the automation of irrigation systems, it was considered only the soil water contents between field capacity and the permanent wilting point.

To estimate the accuracy of the sensor, considering $95 \%$ of probability of occurrence of random error, that is, two standard deviations for more or for less in relation to the estimated value of the water content of soil, it was used the methodology presented by Doebelin (1990). The standard deviation of the estimated soil water content was calculated using Equation 2.

$$
s=\sqrt{\frac{1}{n} \sum_{i=1}^{n}\left[\left(u_{e}-u_{o}\right)_{i}\right]^{2}}
$$


where,

$\mathrm{S}$ - standard deviation of the soil water content, $\mathrm{kg} \mathrm{kg}^{-1}$;

$\mathrm{u}_{\mathrm{e}}$ - estimate value of the soil water content, $\mathrm{kg} \mathrm{kg}^{-1}$;

$\mathrm{u}_{\mathrm{o}}$ - observed value of the soil water content, $\mathrm{kg} \mathrm{kg}^{-1}$, and

$\mathrm{n}$ - total number of observations.

\section{RESULTS AND DISCUSSION}

\section{SENSORS}

Seven sensors were constructed with rods coated with varnish, as shown in Figure 4.

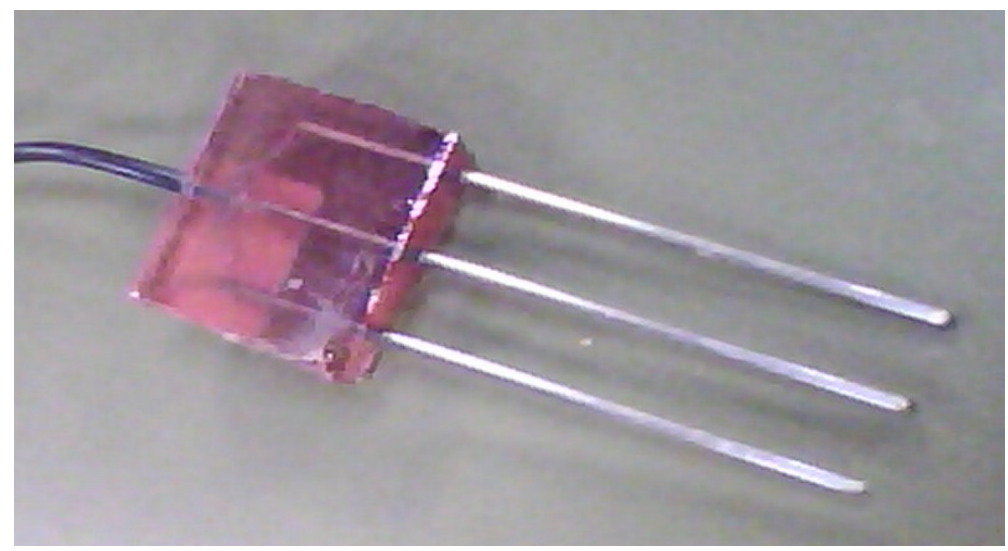

FIGURE 4. Sensor of soil water content with rods coated with varnish.

To verify if the construction procedure of the sensors was uniform, the capacitance of each one was measured in two situations using a digital meter: (i) empty (air between the rods) and (ii) immersed in water. The data obtained are shown in Table 1.

Looking at the data in Table 1, it can be observed that the capacitance values clearly show that there was practically no difference between the sensors, indicating that their construction process was satisfactory.

The electrical resistance of the sensors was also measured in both situations, to verify if the insulating varnish was applied correctly and in sufficient quantity, preventing the electric current from circulating between rods. According to the meter used, the varnish supplied an electrical resistance greater than $40 \mathrm{M} \Omega$ between rods, even in the most critical situation, in which the sensors were immersed in water.

TABLE 1. Capacitance of each sensor with rods coated with varnish, immersed in air and water

\begin{tabular}{ccc}
\hline \multirow{2}{*}{ Sensor Identification } & \multicolumn{2}{c}{ Capacitance $(\mathrm{nF})$} \\
\cline { 2 - 3 } & Immersed in air & Immersed in water \\
\hline 1 & 0.34 & 0.90 \\
3 & 0.35 & 0.87 \\
4 & 0.34 & 0.87 \\
5 & 0.35 & 0.81 \\
6 & 0.35 & 0.80 \\
7 & 0.35 & 0.83 \\
Average & 0.35 & 0.83 \\
\hline Standard Deviation & 0.35 & 0.84 \\
\hline
\end{tabular}


The capacitance data clearly shows that there was practically no difference between the sensors, indicating that their construction process was satisfactory.

The electrical resistance of the sensors was also measured in both situations, to verify if the insulating varnish was applied correctly and in sufficient quantity, preventing the electric current from circulating between rods. According to the meter used, the varnish supplied an electrical resistance greater than $40 \mathrm{M} \Omega$ between rods, even in the most critical situation, in which the sensors were immersed in water.

\section{MEASUREMENT CIRCUIT}

Throughout the experiment, the measurement circuit was mounted in a matrix of contacts. This may have contributed to the appearance of noise in the circuit, affecting its accuracy. To avoid this problem, the final circuit shell be built on a printed circuit board.

\section{CALIBRATION}

According to data from the three replications, a mathematical model was fitted to the experimental data to estimate the water content of the soil between the field capacity (water content equal to $13.4 \%$ weight) and wilting point (water content equal to $7.5 \%$ weight), as a function of the output signal of the sensor. The model was obtained by regression using the least squares method implemented in the Excel spreadsheet.

The model that best fitted to the experimental data was represented by Equation 3, with a determination coefficient equal to $93.17 \%$ indicating that the model explains well the variations in the water content of soil as a function of capacitance.

$$
u_{e}=-4.4685 v^{3}+34.1512 v^{2}-86.665 v+73.13
$$

where,

$\mathrm{u}_{\mathrm{e}}$ - estimated soil water content, $\mathrm{kg} \mathrm{kg}^{-1}$, and

$\mathrm{v}$ - output voltage signal from the sensor, $\mathrm{V}$.

The estimates of the soil water content are plotted in Figure 5, as a function of the voltage signal measured by the sensors.

The graph showing the correlation between the observed and estimated data of the soil water content is shown in Figure 6. According to the fitted model, the sensor showed an accuracy of $\pm 0.010 \mathrm{~kg} \mathrm{~kg}^{-1}$.

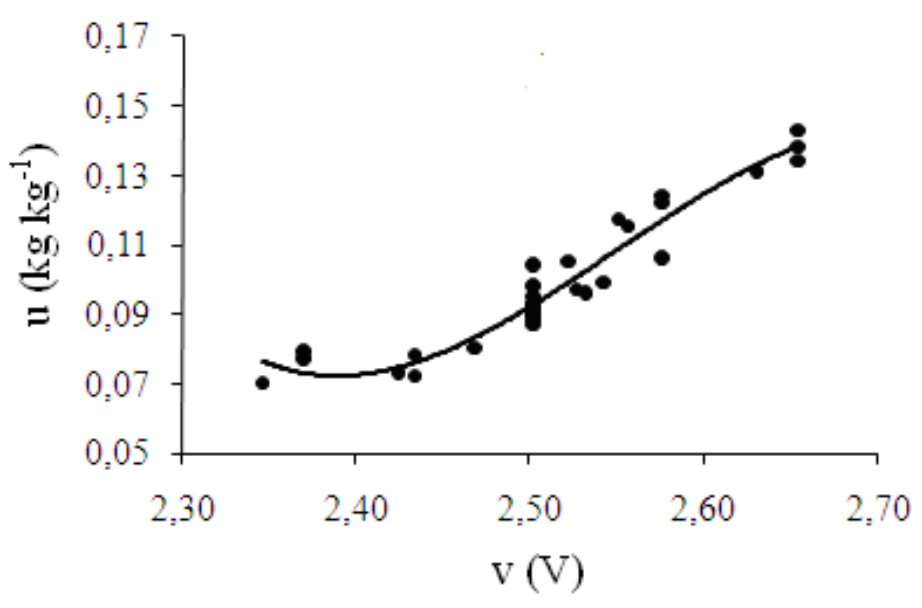

FIGURE 5. Variation of the water content (u), by weight, as a function of the sensor output signal (v). 


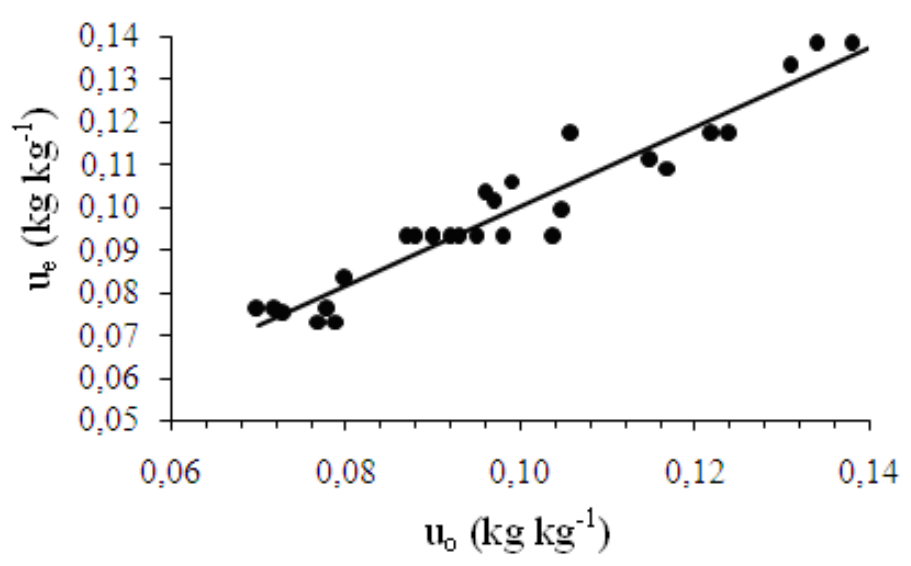

FIGURE 6. Correlation between the estimated $\left(\mathrm{u}_{\mathrm{e}}\right)$ and observed $\left(\mathrm{u}_{\mathrm{o}}\right)$ values of the soil water content.

\section{CONCLUSIONS}

The sensor with rods coated with insulating varnish and its measurement circuit can be used to measure the soil water content with satisfactory accuracy.

Measurements of water content of soil taken with the sensor developed in this work can be used to assist in the implementation of strategies to control and automation of irrigation systems.

For soil water content between the field capacity and wilting point, a high correlation between the water content of soil and the output signal of the sensor was obtained.

\section{ACKNOWLEDGEMENTS}

The authors would like to thank the "Fundação de Amparo à Pesquisa do Estado de Minas Gerais" - FAPEMIG, the "Conselho Nacional de Desenvolvimento Científico e Tecnológico" $\mathrm{CNPq}$, and the Department of Agricultural Engineering of the Federal University of Viçosa, for their support in making this study possible.

\section{REFERENCES}

BERNARDO, S.; SOARES, A.A.; MANTOVANI, E.C. Manual de irrigação. 8.ed. Viçosa: Editora UFV, 2006. $625 \mathrm{p}$.

CRUZ, T.M.L.; TEIXEIRAS, A.S.; CANAFÍSTULA, F.J.F.; SANTOS, C.C.; OLIVEIRA, A.D.S.; DAHER, S. Avaliação de sensor capacitivo para o monitoramento do teor de água do solo. Engenharia Agrícola, Jaboticabal, v.30, n.1, fev. 2010. Disponível em: <http://www.scielo.br /scielo.php?script=sci_arttext\&pid=S0100-69162010000100004\&lng=pt\&nrm=iso $>$. Acesso em: 6 jun. 2010.

DOEBELIN, E. O. Measurement systems: application and design. 4.ed. New York: McGraw-Hill, 1990.

LACERDA, R.D.; GUERRA, H.O.C.; JUNIOR, G.B.; CAVALCANTI, M.L.F. Avaliação de um TDR para determinação do conteúdo de água do solo. Revista de Biologia e Ciências da Terra, Campina Grande, v.5, n.1, 2005.

MANTOVANI, E.C.; BERNARDO, S.; PALARETTI, L.F. Irrigação: princípios e métodos. 2.ed. Viçosa: Editora UFV, 2007. 358 p.

OLIVEIRA FILHO, D.; MONTOVANI, E.C.; RAMOS, M.M.; MARTINS, J.H. Reflectometria no domínio do tempo na determinação do conteúdo de água no solo. Revista Brasileira de Engenharia Agrícola e Ambiental, Campina Grande, v.10, n.2, p.306-314, 2006. 
PAZ, V.P.S.; TEODORO, R.E.F.; MENDONÇA, F.C. Recursos hídricos, agricultura irrigada e meio ambiente. Revista Brasileira de Engenharia Agrícola e Ambiental, Campina Grande, v.4, n.3, Dec. 2000. Disponível em: <http://www.scielo.br/scielo.php?script=sci_arttext\&pid=S1415$43662000000300025 \& \operatorname{lng}=e n \& n r m=i s o>$. Acesso em: 14 jun. 2010.

QUEIROZ, T.M.; CARVALHO, J.A.; RABELO, G.F.; ANDRADE, M.J.B. Avaliação de sistema alternativo de automação da irrigação do feijoeiro em casa de vegetação. Engenharia Agrícola, Jaboticabal, v.25, n.3, p.632-641, 2005. Disponível em: <http://www.scielo.br/pdf/ eagri/v25n3/28058.pdf>. Acesso em: 14 jul. 2009.

SANTOS, M.R. Uso da reflectometria no domínio do tempo para avaliar a distribuição de nitrato e fósforo em colunas de solos fertirrigados. 2008. 59 f. Dissertação (Mestrado em Engenharia Agrícola) - Departamento de Engenharia Agrícola, Universidade Federal de Viçosa, Viçosa - MG, 2008.

SILVA, C.R.; FOLEGATTI, M.V.; SILVA, T.J.A.; ALVES JÚNIOR, J.; SOUZA, F.C.; RIBEIRO, R.V. Water relations and photosynthesis as criteria for adequate irrigation management in 'Tahiti' lime trees. Scientia Agricola, Piracicaba, v.62, p.415-422, 2005.

SILVA, C.R.; ANDRADE JÚNIOR, A.S.; ALVES JÚNIOR, J.; SOUZA, A.B.; MELO, F.B.; COELHO FILHO, M.A. Calibration of a capacitance probe in a Paleudult. Scientia Agricola, Piracicaba, v.64, n.6, dez. 2007. Disponível em: <http://www.scielo.br/scielo.php?

script=sci_arttext\&pid=S0103-90162007000600012\&lng=pt\&nrm=iso $>$. Acesso em: 6 jun. 2010. 